\title{
The last British Ice Sheet: growth, maximum extent and deglaciation
}

\author{
Lindsay J. Wilson, William E. N. Austin \\ \& Eystein Jansen
}

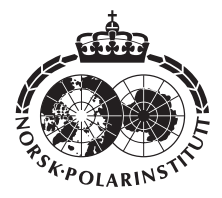

The growth, maximum lateral extent and deglaciation of the last British Ice Sheet (BIS) has been reconstructed using sediment, faunal and stable isotope methods from a sedimentary record recovered from the Barra Fan, north-west Scotland. During a phase of ice sheet expansion postdating the early "warmth" of Marine Isotope Stage 3 (MIS 3), ice rafting events, operating with a cyclicity of approximately 1500 years, are interspersed between warm, carbonate-rich interstadials operating with a strong Dansgaard-Oeschger $(\mathrm{D}-\mathrm{O})$ cyclicity. The data suggest that the BIS expanded westwards to the outer continental shelf break shortly after $30 \mathrm{Ky} \mathrm{BP}$ (before present) and remained there until about 15 Ky BP. Within MIS 2, as the ice sheet grew to its maximum extent, the pronounced periodicities which characterize MIS 3 are lost from the record. The exact timing of the Last Glacial Maximum is difficult to define in this record; but maxima in Neogloboquadrina pachyderma (sinistral) $\delta^{18} \mathrm{O}$ are observed between 21 - $17 \mathrm{Ky} \mathrm{BP}$. A massive discharge of ice-rafted detritus, coincident with Heinrich event 1, is observed at about 16 Ky BP. Deglaciation of the margin is complete by about $15 \mathrm{Ky}$ $\mathrm{BP}$ and surface waters warm rapidly after this date.

L. J. Wilson \& W. E. N. Austin, School of Geography and Geosciences, University of St. Andrews, St. Andrews, Fife, Scotland KY16 9AL, UK; E. Jansen, Dept. of Geology, University of Bergen, Allégaten 41, N-5007 Bergen, Norway.

The growth and decay of Northern Hemisphere ice sheets is a persistent feature of the late Pleistocene and glacier-influenced sedimentation is therefore a characteristic depositional feature of the North East Atlantic margins (e.g. Andrews et al. 1996). Continental margin sediments which predate the Last Glacial Maximum (LGM) have the potential to provide millennial-scale records of ice sheet dynamics (Bond \& Lotti 1995; Knutz et al. 2001). These regional records highlight the significance of local ice sheet variability, set in the wider context of north-east Atlantic ice rafting and palaeoclimate changes.

Rapid warm-to-cold climate transitions (Dansgaard-Oeschger [D-O] events), occurring with periodicities of 500-2000 years (e.g. Dansgaard et al. 1993; Bond et al. 1999), characterize the last glacial period. These persistent cycles of the North Atlantic's climate system, coupled to freshwater forcing mechanisms, may explain the global significance of such ice rafting events (Broecker et al. 1990; Bond et al. 1999).

The contribution of the last British Ice Sheet (BIS) to North Atlantic ice-rafted debris (IRD) and freshwater forcing mechanisms is unlikely to be large, yet the BIS may serve as a sensitive indicator of climate forcing upon northern hemisphere glacier response (e.g. Boulton 1990). Richter et al. (2001), in a review of the BIS contribution to North Atlantic IRD, have shown how IRD records can be related to late Devensian $(\sim 30 \mathrm{Ky} \mathrm{BP})$ ice advances from the south-west 


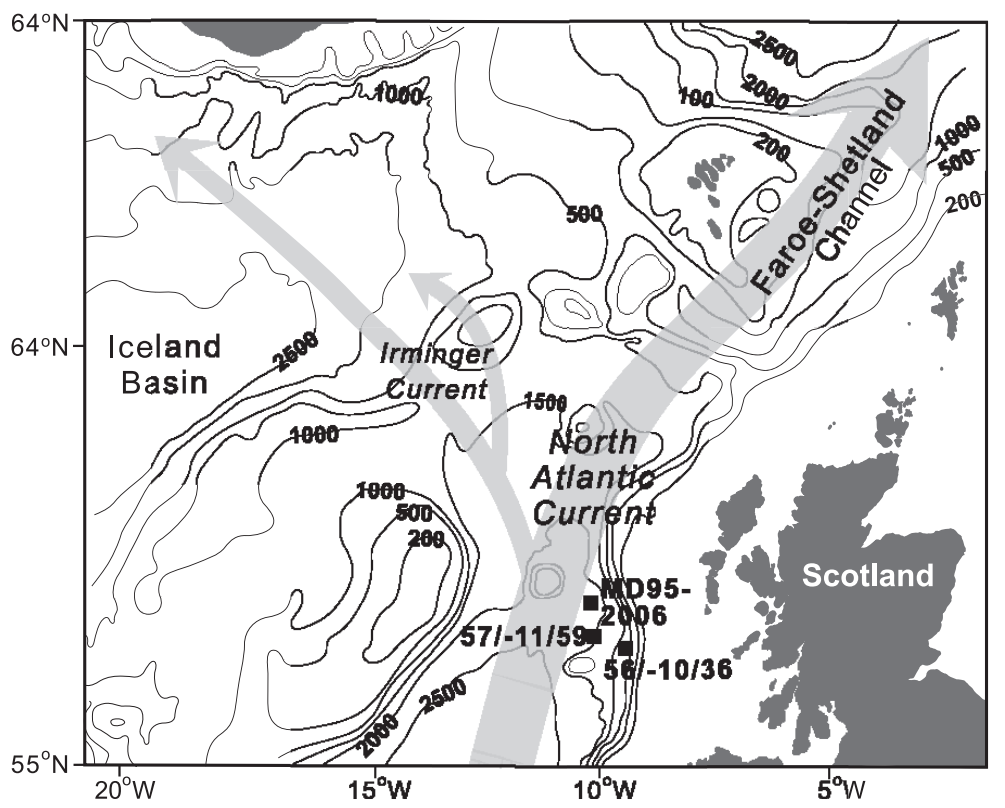

Fig. 1. Location of marine core MD95-2006 $\left(57^{\circ} 01.82^{\prime} \mathrm{N}\right.$, $10^{\circ} 03.48^{\prime} \mathrm{W}$, water depth $2120 \mathrm{~m}$ ) from the Barra Fan, north-west Scotland (based on Kroon et al. 1997 and used with permission of Paleoceanography/American Geophysical Union). British Geological Survey cores 56/-10/ 36 and $57 /-11 / 59$ are also shown.

sector of the BIS. In a detailed investigation of Heinrich event 2 at the Goban Spur, Scourse et al. (2000) demonstrated a precursor event of British origin, predating the main Laurentide IRD signature. This dynamic response of the last BIS has also been documented by Knutz et al. (2001), who suggested a strong regional IRD signature closely coupled to the $\mathrm{D}-\mathrm{O}$ climate cycle.

The aim of this paper is to present evidence for the dynamic nature of the BIS during the last glacial period. In addition the chronology of the main MIS transitions and the related growth, maximum extent and collapse of the ice sheet is evaluated from marine sediment core MD95-2006.

\section{Giant piston core MD95-2006}

Giant piston core MD95-2006 (57 01.82' N, $10^{\circ} 03.48^{\prime} \mathrm{W}$, water depth $2120 \mathrm{~m}$ ) was recovered in 1995 by the RV Marion Dufresne from the northern limits of the Barra Fan, north-west Scotland, as part of the International Marine Past Global Changes Project (IMAGES) programme (Fig. 1). Evidence of late Pleistocene glacial activity is present on the shelf margin in the form of morainal banks (Selby 1989; Stoker 1995; Austin \& Kroon 1996) and iceberg plough marks (Kenyon 1987).

Two vibrocores from the St. Kilda Basin of the Hebridean Shelf (57/-09/89 and 57/-09/46) document the timing of the final deglaciation of the shelf from this region of north-west Scotland and provide an unprecedented record of the Younger Dryas cold phase (Austin 1991; Peacock et al. 1992; Austin et al. 1995; Austin \& Kroon 1996). The detailed record of deglaciation from two short cores on the Barra Fan (56/$10 / 36$ and $57 /-11 / 59$ ) which postdate $15 \mathrm{Ky} \mathrm{BP}$ are documented by Kroon et al. (1997) and the associated deep-water circulation changes by Austin \& Kroon (2001). Piston core MD95-2006 recovered $30 \mathrm{~m}$ of distal glacimarine sediments with average accumulation rates of greater than $0.5 \mathrm{~m} / \mathrm{Ky}$ (Kroon et al. 2000; Knutz et al. 2001). It therefore exhibits the potential for high resolution marine sediment studies over MIS 2 and 3 from a continental margin setting which is known to record the major fluctuations of the last BIS. This paper presents new planktonic foraminiferal stable isotope data from core MD95-2006 and a refined interpretation of BIS dynamics within the context of north-east Atlantic palaeoceanography.

\section{Methods}

\section{Calcium carbonate}

Calcium carbonate content was determined down- 

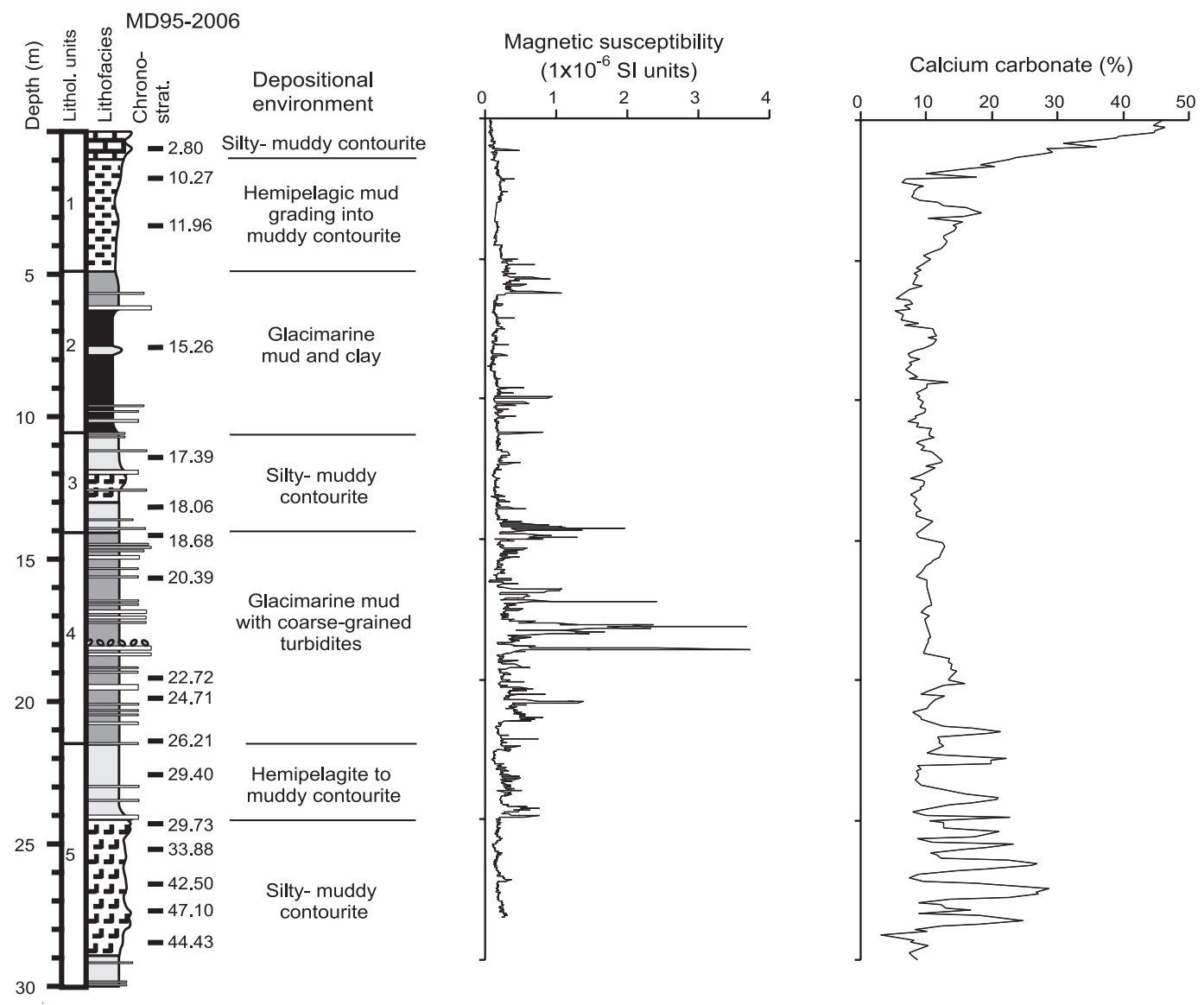

Fig. 2. Lithological $\log$ with additional radiocarbon ages (Ky) indicated (figure modified from Kroon et al. 2000 and printed with permission of the Journal of the Geological Society). Calcium carbonate is weight \%.

core at $10 \mathrm{~cm}$ intervals using a modified back titration method (Grimaldi et al. 1966), as described in Austin \& Kroon (1996) and Austin \& Evans (2000). $0.5 \mathrm{~g}$ of dry sediment was accurately weighed and treated with an excess of acid (25 $\mathrm{ml}$ of $0.5 \mathrm{M} \mathrm{HCl}$ solution). $0.5 \mathrm{ml}$ of bromophenol blue indicator was added and the solution was back-titrated against $0.35 \mathrm{M} \mathrm{NaOH}$ solution until the yellow to violet end-point was reached. The calcium carbonate content was calculated (weight in grams, volume in litres) by:

$$
\begin{gathered}
\% \mathrm{CaCO}_{3}= \\
100[(\text { vol. } \mathrm{HCl} \times \text { molarity } \mathrm{HCl} \times 1.007225)- \\
(\text { vol. } \mathrm{NaOH} \times \text { molarity } \mathrm{NaOH})] \\
\times(2 \times \text { sample weight })^{-1} \times 100
\end{gathered}
$$

Wilson et al. 2002: Polar Research 21(2), 243-250

\section{Magnetic susceptibility}

The volumetric magnetic susceptibility was measured down-core in SI units in $1 \mathrm{~cm}$ increments using a Bartington Instruments magnetic susceptibility meter (Model MS2, adapted with a MS2F probe with an operating frequency of $0.58 \mathrm{~Hz}$ ). The results are reported as $1 \times 10^{-6}$ SI units.

\section{Stable isotopes}

Stable isotope measurements were performed on a Finnigan MAT 251 mass spectrometer at the University of Bergen, Norway. The $\delta^{18} \mathrm{O}$ isotope results were obtained from the analysis of the planktonic foraminifera Neogloboquadrina pachyderma (sinistral) and Globigerina bulloi- 
des. The foraminifera were processed from the $>63 \mu \mathrm{m}$ washed residues and picked from the size range $>150 \mu \mathrm{m}$ from the dry sieved residues. Sample weights, typically 10 specimens, were in the range 0.090-0.105 $\mathrm{mg}$. Results are reported with respect to Vienna Pee Dee Belemnite (VPDB) standard through calibration with the National Institute of Standards and Technology (NIST) 19 standard. The reproducibility of the system for $\delta^{18} \mathrm{O}$ is $\pm 0.07 \%$ based on replicate measurements of an internal carbonate standard $(0.1 \pm 0.05 \mathrm{mg})$.

\section{Results}

\section{Lithostratigraphy}

The lithostratigraphy of core MD95-2006 is summarized in Fig. 2 (see Kroon et al. 2000; Knutz et al. 2001; Wilson \& Austin 2002).

Down-core variability is highlighted by magnetic susceptibility measurements. Below $5 \mathrm{~m}$, the first in a series of marked peaks in magnetic susceptibility are observed, many of these coinciding with silty to sandy muds, containing dropstones and previously interpreted as IRD events (Knutz et al. 2001). The most pronounced magnetic susceptibility events are recorded at approximately $10 \mathrm{~m}, 15 \mathrm{~m}, 17-19 \mathrm{~m}, 21 \mathrm{~m}$ and $24.5 \mathrm{~m}$. Between 14 and $24 \mathrm{~m}$ core depth, the silty to sandy muds are interspersed with numerous sandy turbidites and occasional gravel layers. Calcium carbonate values in MD95-2006 are generally low $(<15 \%)$ between $6-19 \mathrm{~m}$, coinciding with an interval of prominent magnetic susceptibility peaks and increased clay content. Below $19 \mathrm{~m}$, values exhibit a pronounced cyclicity, ranging between 10 and $25 \%$ calcium carbonate content (Fig. 2). These carbonate-rich intervals are observed to contain increased abundances of $G$. bulloides and other temperate planktonic foraminifera.

\section{Chronostratigraphy}

Seventeen ${ }^{14} \mathrm{C}$ accelerator mass spectrometry (AMS) radiocarbon dates were obtained from core MD95-2006 (Fig. 3), based upon monospecific foraminiferal samples of sub-polar $G$. bulloides and polar N. pachyderma (sin.). Samples were prepared to graphite at the Natural Environment Research Council (NERC) Radio-

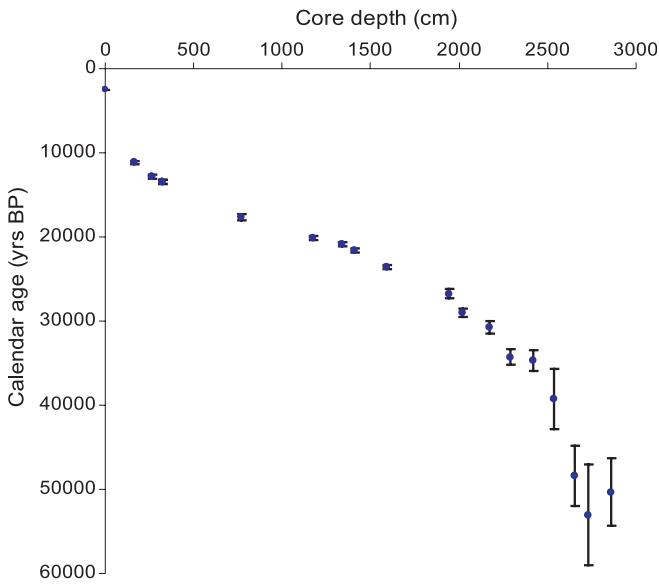

Fig. 3. Age-depth model of core MD95-2006.

carbon Laboratory, East Kilbride, and ${ }^{14} \mathrm{C}$ measurements were made at the University of Arizona NSF-AMS facility. One tephra layer (1 Thol. 2 Ash) was identified to further constrain the Younger Dryas period. This is a constituent of North Atlantic Ash Zone 1 (Kvamme et al. 1989) and provides a useful chronostratigraphic marker within an interval of significant radiocarbon dating uncertainty (e.g. Austin et al. 1995).

Five ${ }^{14} \mathrm{C}$ ages were calibrated into calendar ages using the Calib4.2 programme (Stuiver \& Reimer 1993; Stuiver et al. 1998) which incorporates a 400 year correction for the modern surface ocean reservoir effect at this latitude. This calibration of ${ }^{14} \mathrm{C}$ ages was only applied to radiocarbon dates younger than $21000{ }^{14} \mathrm{C}$ years; the calibration data set available beyond this age is limited and has significantly decreased reliability. The nine remaining ${ }^{14} \mathrm{C}$ dates were calibrated using the U/Th ages and secondorder polynomial equation of Bard et al. (1998) which statistically extends the current coral calibration set of Stuiver et al. (1998). Full chronostratigraphic details of this record are included in Wilson \& Austin (2002).

Fig. 4 (opposite page). Summary figures of magnetic susceptibility, calcium carbonate content and uncorrected planktonic foraminiferal $\delta^{18} \mathrm{O}$ from core MD95-2006 with Greenland Ice Sheet Project (GISP2) ice core $\delta^{18} \mathrm{O}$ (Grootes et al. 1993). Interstadials are numbered after Dansgaard et al. (1993). Shading represents the Heinrich events as defined by Bond et al. (1999). MIS1-4 are indicated, after Martinson et al. (1997). Ages for MD95-2006 are calibrated (Ky BP). 

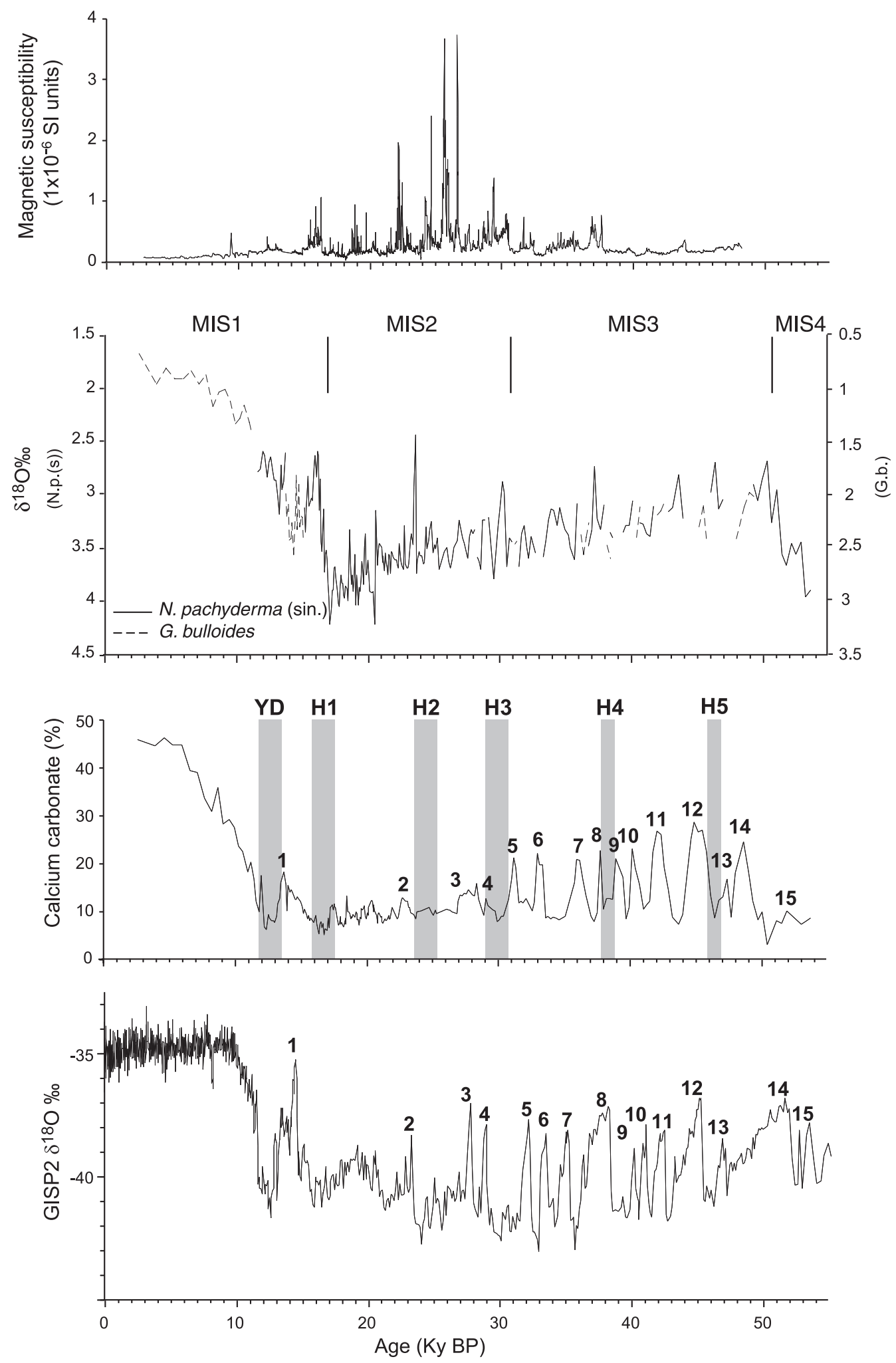

Wilson et al. 2002: Polar Research 21(2), 243-250 


\section{Stable isotopes}

The $\delta^{18} \mathrm{O}$ stratigraphy of core MD95-2006 is presented in Fig. 4. A marked decrease in $\delta^{18} \mathrm{O}$, with a mid-point at about $52 \mathrm{Ky} \mathrm{BP}$ is interpreted to represent the MIS 4/3 transition. This transition is also characterized by a prominent minimum in $\delta^{13} \mathrm{C}$ (Wilson, unpubl. data). The early part of MIS 3 is characterized by a series of cycles in $\delta^{18} \mathrm{O}$, corresponding to marked changes in planktonic foraminiferal assemblage composition. The transition to MIS 2 is not prominent in the $\delta^{18} \mathrm{O}$ record at this site, but can be defined from other proxies, such as the increase in IRD at about 30 Ky BP (Wilson \& Austin 2002). Planktonic foraminiferal $\delta^{18} \mathrm{O}$ reach their most positive values within the latter part of MIS2, between 20.5 - 17.5 Ky BP, which is consistent with other North Atlantic records (e.g. V29-204, Curry et al. 1999). The first in a series of marked shifts towards lighter $\delta^{18} \mathrm{O}$ occur shortly after $17 \mathrm{Ky}$ BP and herald the onset of Termination 1. The deglacial $\delta^{18} \mathrm{O}$ record of MD95-2006 agrees well with previously published records postdating 15 Ky BP from this margin (e.g. Kroon et al. 1997; Austin \& Kroon 2001). Whilst the MIS stage boundaries are not used as control points in the age-depth model of core MD95-2006, they do provide a valuable check on the calendar ages derived from the corrected and calibrated AMS ${ }^{14} \mathrm{C}$ dating.

\section{Discussion}

Despite recent speculation on BIS variability through the last glacial period (e.g. Bowen et al. 2002), there remains considerable uncertainty regarding the dynamics of the last ice sheet prior to the LGM (Clapperton 1995). The offshore record of core MD95-2006 provides an opportunity to investigate the distal sedimentological response of glacimarine processes at this margin over the last 55000 years. The lithostratigraphy of core MD95-2006 has been published previously by Kroon et al. (2000), Knutz et al. (2001), and Wilson \& Austin (2002). These investigations demonstrate the significance of the IRD signature, interpreted from clast counts, magnetic susceptibility and spectrophotometry, and highlight the dynamic nature of the last BIS. Here, the growth, maximum extent and deglaciation of the BIS are discussed within the context of a complete planktonic foraminiferal $\delta^{18} \mathrm{O}$ record.

In general, $\delta^{18} \mathrm{O}$ exhibits an overall cooling trend through MIS 3, from an initial warm phase above the MIS 4/3 transition (Fig. 4). However, because of major planktonic foraminiferal assemblage changes, the $\delta^{18} \mathrm{O}$ signal alternates between two species, $N$. pachyderma (sin.) and $G$. bulloides. These assemblage changes reflect surface water mass transitions above the core site, comparable to those described for the last deglaciation (Kroon et al. 1997). Ten well-defined concentration peaks in calcium carbonate content are observed within MIS 3, with an average periodicity of 2000 years. These interstadial events were assigned to Greenland interstadial events 5 - 14 (Dansgaard et al. 1993) by Wilson \& Austin (2002). Sediment accumulation rates are reduced during the MIS 3 interstadials because glacier retreat would have led to sediment entrapment on the continental shelf and shelf break. There is some evidence in the literature which suggests enhanced ventilation during the interstadials of MIS 3 (e.g. Curry et al. 1999), which would also act to increase bottom current strength, reduce clay contents, and therefore increase relative carbonate content.

The stadials of MIS 3 are characterized by clearly defined IRD events, which carry a BIS signal (Knutz et al. 2001). This record, constrained by planktonic $\delta^{18} \mathrm{O}$, demonstrates the dynamic nature of the BIS within MIS 3. This stadial/interstadial pattern of IRD-rich/carbonaterich deposits illustrates the nature of the North Atlantic "Bond cycle" (Bond et al. 1993; Bond \& Lotti 1995). In addition, Heinrich events H1 to $\mathrm{H} 5$ are identified at this site (Fig. 4) and clearly correspond to low planktonic $\delta^{18} \mathrm{O}$ values. These IRD events and low $\delta^{18} \mathrm{O}$ excursions suggest significant meltwater influence.

A transition, at approximately $30 \mathrm{Ky} \mathrm{BP,}$ from silty-muddy contourites to hemipelagite to muddy contourite sediments marks the transition from MIS 3 to MIS2 (Knutz et al. 2001). The timing of the transition in MD95-2006 agrees with the age estimate from GISP2 and VM19-30 reported by Bond et al. (1997, 1999). Interestingly, Bond et al. (1999) note a discontinuous record of Icelandic glass below $400 \mathrm{~cm}$ (about 32 Kya) in core VM23-81, which they interpret as being outside ("downstream") the main Ruddiman IRD belt (Ruddiman 1977). It is also likely that the quantity of IRD from the smaller north-east Atlantic ice sheets (e.g. BIS, 
Iceland) was considerably less prior to regional ice sheet expansion after $30 \mathrm{Ky}$ BP.

Sejrup et al. (1994) identified the maximum Weichselian glaciation in the northern North Sea between 29.4 and 22 Ky BP. Bowen et al. (2002) follow the recommendation of the EPILOG project, which defines the LGM between 19 and $23 \mathrm{Ky} \mathrm{BP}$. The precise timing of the LGM is difficult to define in core MD95-2006. At this location the advance of the last BIS ice margin can be seen approaching the shelf break at $30 \mathrm{Ky}$ BP. Delivery of IRD to the core site is greatly enhanced as the ice sheet reaches its maximum extent. The $N$. pachyderma ( $\sin$.) $\delta^{18} \mathrm{O}$ show maxima (cold, polar water) between 21 - 17 Ky BP.

At its maximum extent, lying on deformable sediments, the last BIS had the potential to respond rapidly to both internal and external forcing mechanisms. Factors such as sea level rise, coupled with glacier dynamics, would have generated a very unstable response at the ice margin. This instability is convincingly illustrated by two major MIS 2 IRD events (Fig. 4), which coincide with pronounced $\delta^{18} \mathrm{O}$ minima (H2 at $24 \mathrm{Ky} \mathrm{BP}$; $\mathrm{H} 1$ at $16.5 \mathrm{Ky} \mathrm{BP})$.

Deglaciation, following H1, is rapid, but is punctuated by a clear return to polar conditions, before the incursion of North Atlantic Current waters at 15 Ky BP. After this time, surface waters warm rapidly and our records are generally consistent with those of Kroon et al. (1997) which describe the Late glacial period in greater detail. A final, minor phase of ice rafting is resolved during the Younger Dryas stadial, but this is unlikely to derive from the BIS, which at this time is believed to have been restricted to the mountain valleys of north-west Scotland (Benn 1997).

\section{Summary and conclusions}

The records obtained from MD95-2006 reveal how ice sheet extent influences sediment delivery rates across the shelf-slope break. The response of the BIS across the MIS 3-2 transition is clearly defined in a large number of sedimentological proxies and illustrates the highly responsive nature of this ice sheet to external climate forcing and climate cooling at about $30 \mathrm{Ky}$ BP. Major ice rafting events indicative of Scottish IRD provenance, coincident with the North Atlantic Heinrich events, are clearly defined in this record and are synchronized with low $\delta^{18} \mathrm{O}$ events. The LGM is not clearly resolved, but can be inferred from $\delta^{18} \mathrm{O}$ maxima between 21 - $17 \mathrm{Ky}$ BP. Deglaciation of the margin is largely achieved through H1, but climate remains cold until about $15 \mathrm{Ky} \mathrm{BP}$, when a transition from polar to North Atlantic Current assemblages is identified.

Acknowledgements.-LJW gratefully acknowledges the support of the European Union Marie Curie Pre-doctoral Fellowship and the University of Bergen in obtaining the planktonic stable isotope data. R. Sørås assisted with mass spectrometer operation. We thank T. O. Vorren and an anonymous referee for their helpful and constructive comments. M. Currie and C. Bryant, NERC Radiocarbon Laboratory, supported the AMS dating programme. We are grateful to the captain and crew of the RV Marion Dufresne and to L. Labeyrie, in particular. LJW's PhD study is funded by the University of St. Andrews. This work is supported by NERC, through grants GST/02/723; GST/02/1174; GR9/01595'A'.

\section{References}

Andrews, J. T., Austin, W. E. N., Bergsten, H. \& Jennings, A. E. 1996: The Late Quaternary palaeoceanography of North Atlantic margins: an introduction. In J. T. Andrews et al. (eds): Late Quaternary palaeoceanography of the North Atlantic margins. Spec. Publ. 111. Pp. 1-6. Geological Society of London.

Austin, W. E. N. 1991: Late Quaternary benthonic foraminiferal stratigraphy of the western UK continental shelf. $\mathrm{PhD}$ thesis, University of Wales.

Austin, W. E. N., Bard, E., Hunt, J. B., Kroon, D. \& Peacock, J. D. 1995: The ${ }^{14} \mathrm{C}$ age of the Icelandic Vedde Ash: implications for Younger Dryas marine reservoir age corrections. Radiocarbon 37, 53-62.

Austin, W. E. N. \& Evans, J. R. 2000: North East Atlantic benthic foraminifera: modern distribution patterns and palaeoecological significance. J. Geol. Soc. 157, 679-691.

Austin, W.E. N. \& Kroon, D. 1996: Late glacial sedimentology, foraminifera and stable isotope stratigraphy of the Hebridean continental shelf, northwest Scotland. In J. T. Andrews et al. (eds): Late Quaternary palaeoceanography of the North Atlantic margins. Spec. Publ. 111. Pp. 187-213. Geological Society of London.

Austin, W. E. N. \& Kroon, D. 2001: Deep sea ventilation of the northeastern Atlantic during the last 15,000 years. Glob. Planet. Change 30, 13-31.

Bard, E., Arnold, M., Hamelin, B., Tisnerat-Laborde, N. \& Cabioch, G. 1998: Radiocarbon calibration by means of mass spectrometric $\mathrm{Th}^{230} / \mathrm{U}^{234}$ and $\mathrm{C}^{14}$ ages of corals: an updated database including samples from Barbados, Mururoa and Tahiti. Radiocarbon 40, 1085-1092.

Benn, D. I. 1997: Glacier fluctuations in western Scotland. Quat. Int. 38/39, 137-149.

Bond, G. C., Broecker, W., Johnsen, S., McManus, J., Labey- 
rie, L., Jouzel, J. \& Bonani, G. 1993: Correlations between climate records from North Atlantic sediments and Greenland ice. Nature 365, 143-147.

Bond, G. C. \& Lotti, R. 1995: Iceberg discharges into the North Atlantic on millennial time scales During the last glaciation. Science 267, 1005-1010.

Bond, G. C., Showers, W. J., Cheseby, M., Lotti, R., Almasi, P., de Menocal, P., Priore, P., Cullen, H., Hajdas, I. \& Bonani, G. 1997: A pervasive millennial-scale cycle in North Atlantic Holocene and glacial climates. Science 278, 12571266

Bond, G. C., Showers, W., Elliot, M., Evans, M., Lotti, R., Hajdas, I., Bonani, G. \& Johnson, S. 1999: The North Atlantic's 1-2 kyr climate rhythm: relation to Heinrich events, Dansgaard/Oeschger cycles and the Little Ice Age. In P. U. Clark et al. (eds): Mechanisms of global climate change at millennial time scales. Geophys. Monogr. 112. Pp. 35-58. Washington, D.C.: American Geophysical Union.

Boulton, G. S. 1990: Sedimentary and sea level changes during glacial cycles and their control on glacimarine facies architecture. In J. A. Dowdeswell \& J. D. Scourse (eds): Glacimarine environments: processes and sediments. Spec. Publ. 53. Pp. 15-52. Geological Society of London.

Bowen, D. Q., Philips, F. M., McCabe, A. M., Knutz, P. C. \& Sykes, G. A. 2002: New data for the Last Glacial Maximum in Great Britain and Ireland. Quat. Sci. Rev. 21, 89-101.

Broecker, W. S., Bond, G., Klas, M., Bonani, G. \& Wolfi, W. 1990: A salt oscillator in the glacial Atlantic? Paleoceanography 5, 469-477.

Clapperton, C. M. 1995: Fluctuations of local glaciers at the termination of the Pleistocene; $18-8$ ka BP. Quat. Int. 28, 41-50.

Curry, W. B., Marchitto, T. M., McManus, J. F., Oppo, D. W. \& Laarkamp, K. L. 1999: Millennial-scale changes in ventilation of the thermocline, intermediate, and deep waters of the glacial North Atlantic. In P. U. Clark et al. (eds): Mechanisms of global climate change at millennial time scales. Geophysical Monograph 112. Pp. 59-76. Washington, D.C.: American Geophysical Union.

Dansgaard. W., Johnsen, S. J., Clausen, H. B., Dahl-Jensen, D., Gundestrup, N. S., Hammer, C. U., Hvidberg, C. S., Steffenson, J. P., Sveinbjörnsdottir, A. E., Jouzel, J. \& Bond, G. 1993: Evidence for general instability of past climate from a 250-kyr ice-core record. Nature 364, 218-220.

Grimaldi, F. S., Shapiro, L. \& Schnepfe, M. 1966: Determination of carbon dioxide in limestone and dolomite by acidbase titration. US Geol. Surv. Prof. Pap. 550, 186-188.

Grootes, P., Stuiver, M., White, J. W. C., Johnsen, S. \& Jouzel, J. 1993: Comparison of oxygen isotope records from the GISP2 and GRIP Greenland ice cores. Nature $366,552-554$

Kenyon, N. H. 1987: Mass-wasting features on the continental slope of northwest Europe. Mar. Geol. 74, 57-77.

Knutz, P. C., Austin, W. E. N. \& Jones, E. J. W. 2001: Millennial-scale depositional cycles related to British Ice Sheet variability and North Atlantic paleocirculation since 45 kyr B.P., Barra Fan, U.K. margin. Paleoceanography 16, 53-64.

Kroon, D., Austin, W. E. N., Chapman, M. R. \& Ganssen,
G. M. 1997: Deglacial surface circulation changes in the northeastern Atlantic: temperature and salinity records off NW Scotland on a century scale. Paleoceanography $12,755-763$

Kroon, D., Shimmield, G., Austin, W. E. N., Derrick, S., Knutz, P. \& Shimmield, T. 2000: Century- to millennialscale sedimentological-geochemical records of glacialHolocene sediment variations from the Barra Fan (NE Atlantic). J. Geol. Soc. 157, 643-653.

Kvamme, T., Mangerud, J., Furnes, H. \& Ruddiman, W. 1989: Geochemistry of Pleistocene ash zones in cores from the North Atlantic. Nor. Geol. Tidsskr. 69, 251-272.

Martinson, D. G., Pisias, N. G., Hays, J. D., Imbrie, J. Moore, T. C. \& Shackleton, N. 1987: Age dating and the orbital theory of the ice ages: development of a high-resolution 0 to 3000,000-year chronostratigraphy. Quat. Res. 27, 1-29.

Peacock, J. D., Austin, W. E. N., Selby, I., Harland, R., Wilkinson, I. P. \& Graham, D. K. 1992: Late Devensian and Holocene palaeoenvironmental changes on the Scottish continental shelf west of the Outer Hebrides. J. Quat. Sci. 7 145-161.

Richter, T. O., Lassen, S., van Weering, T. C. E. \& de Haas, H. 2001: Magnetic susceptibility patterns and provenance of ice-rafted material at Feni Drift, Rockall Trough: implications for the history of the British-Irish Ice Sheet Mar. Geol. 173, 37-54.

Ruddiman, W. F. 1977: Late Quaternary deposition of icerafted sand in the subpolar North Atlantic (lat $40^{\circ}$ to $65^{\circ} \mathrm{N}$ ), Geol. Soc. Amer. Bull. 88, 1813-1827.

Scourse, J. D.; Hall, I. R.; McCave, I. N., Young, J. R. \& Sugdon, C. 2000: The origin of Heinrich layers: evidence from $\mathrm{H} 2$ for European precursor events. Earth Planet. Sci. Lett. 182, 187-195.

Sejrup, H. P., Haflidason, H., Aarseth, I., King, E., Forsberg, C. F., Long, D. \& Rokoengen, K. 1994: Late Weichselian glaciation history of the northern North Sea. Boreas 23, $1-13$.

Selby, I. 1989: The Quaternary geology of the Hebridean continental margin. $\mathrm{PhD}$ thesis, University of Nottingham. Stoker, T. 1995: The influence of glacigenic sedimentation on slope-apron development on the continental margin off northwest Britain. In R. A. Scrutton et al. (eds) The tecton ics, sedimentation and palaeoceanography of the North Atlantic region. Spec. Publ. 90. Pp. 159-178. Geological Society of London.

Stuiver, M. \& Reimer, P. J. 1993: Extended ${ }^{14} \mathrm{C}$ database and revised CALIB $3.0{ }^{14} \mathrm{C}$ age calibration program. In $\mathrm{M}$ Stuiver \& R. S. Kra (eds): Calibration 1993. Radiocarbon $35,215-230$.

Stuiver, M., Reimer, P. J., Bard, E., Beck, J. W., Burr, G. S., Hughen, K. A., Kromer, B., McCormac, G., van der Plicht, J. \& Spurk, M. 1998: INTCAL98 Radiocarbon age calibration, 24,000 - 0 cal BP. Radiocarbon 40, 1041-1083.

Wilson, L. J. \& Austin, W. E. N. 2002: Millennial and submillennial-scale variability in sediment colour from the Barra Fan, NW Scotland: implications for British ice sheet dynamics. In J. A. Dowdeswell \& C. ÓCofaigh (eds) Glacier-influenced sedimentation on high-latitude continental margins. Spec. Publ. 203. Pp. 349-365. Geological Society of London. 